\title{
Caveat Compounder: A Warning about Using the Daily CRSP Equal-Weighted Index to Compute Long-Run Excess Returns
}

\author{
Linda Canina \\ Cornell University \\ Roni Michaely \\ Cornell University \\ Richard Thaler \\ University of Chicago \\ Kent Womack \\ Dartmouth College
}

Note
Canina and Michaely are at Cornell, Thaler is at the University of Chicago and NBER, and Womack is at Dartmouth. We would like to thank Rene Stulz (the editor), John Heaton, Andy Lo, David Scharfstein, Rob Stambaugh, B. Swaminathan, Jiang Wang, and an anonymous referee for helpful comments and discussions. We retain full responsibility for any remaining errors.




\begin{abstract}
This paper issues a warning that compounding daily returns of the Center for Research in Security Prices (CRSP) equal-weighted index can lead to surprisingly large biases. The differences between the monthly returns compounded from the daily tapes and the monthly CRSP equal-weighted indices is almost 0.43 percent per month, or 6 percent per year. This difference amounts to one-third of the average monthly return, and is large enough to reverse the conclusions of a paper using the daily tape to compute the return on the benchmark portfolio. We also investigate the sources of these biases and suggest several alternative strategies to avoid them.
\end{abstract}




\section{Caveat Compounder: A Warning about Using the Daily CRSP Equal-Weighted Index to Compute Long-Run Excess Returns}

Since the discovery of the small firm effect (e.g., Reinganum (1981), Keim (1983)) and other long-term pricing abnormalities, such as overreaction (e.g., DeBondt and Thaler (1985)), it has become more common in empirical finance to compute excess returns for periods of up to five years. More recently, research has found surprising excess returns after specific company announcements such as earnings reports (Bernard and Thomas (1989)), IPOs (Ritter (1991)), share repurchases (Ikenberry, Lakonishok, and Vermaelen (1995)), and dividend omissions (Michaely, Thaler, and Womack (1995)). In these long-term event studies it is crucial for the experiment to begin on the exact date of the announcement. Thus, it is necessary to use the daily version of the Center for Research in Security Prices (CRSP) returns tape, and it is only natural for researchers to try to use this same tape as a source for benchmark returns.

The purpose of this paper simply is to issue a warning that compounding daily returns for the equal-weighted (EW) index can lead to biases that are surprisingly large. Of course, since the papers by Blume and Stambaugh (1983) and Roll (1983), most financial economists (should) know that compounding the returns on any portfolio, other than the value-weighted (VW) index portfolio, induces an upward bias in long-term returns (see Blume and Stambaugh (1983, p. 404)). However, a casual poll of empirical finance researchers suggests that only the most frequent users of these data sources have a good sense of how large the biases of this sort can be. So, in the interest of preventing serious errors, we offer three tables that show the difference between returns taken from two CRSP sources, the daily returns tape and the monthly returns tape. We do so for both the equal-weighted and value-weighted indexes. Although no bias is 
expected in the value- weighted index, we include these in the tables as a basis for comparison and as a check on our methods; however, these results are not discussed at any length.

Section I of the paper explains the calculation of compound returns. Because the differences between the compounded daily returns and the monthly returns are so large for the equal-weighted index-larger than most researchers would guess-in Section II we investigate how much of the difference can be explained by the factors highlighted by Blume and Stambaugh (1983) and Roll (1983), e.g., daily autocorrelations and bid-ask bounces. We find that about half of the monthly variation in this difference can be explained by such factors, though not always in the direction predicted by the theory. Section III concludes the article with several suggestions on how to use an equal-weighted index without introducing unnecessary bias.

\section{Calculating Monthly Returns Using the Monthly and the Daily Indices}

In Table I we calculate the monthly returns on the two indices in two ways. Either we compute the monthly return on the index by compounding the daily observations, or we report the monthly return from the tape. Calculating the monthly return from a daily index (either equal-weighted or value-weighted) can be written as follows:

$$
R_{m, \tau}^{d}=\prod_{t}\left(1+R_{d, t, \tau}\right)-1
$$

where $R_{m, \tau}^{d}$ is the monthly return calculated from the daily index, $R_{d, t, \tau}$ is the CRSP daily index, which we calculate as $\left(1 / \Sigma w_{i}\right) \Sigma_{i=1, \ldots, n} w_{i} R_{i}$, where $R_{i}$ is the daily return for security $I$, for holding period $\tau$. For the EW index, $w_{i}$ equals one for all securities, and for the VW index $w_{i}$ is 
the market value of the firm's equity. Using the CRSP monthly index is equivalent to calculating returns as follows:

$$
R_{m, \tau}=\frac{1}{N} \sum_{N}\left(\prod_{t}\left\{1+R_{d, t, \tau}\right\}-1\right),
$$

where, $R_{m, \tau}$ is the CRSP monthly index.

Table I shows the average values for $R_{m, \tau}$ and $R_{m, \tau}^{d}$ for each of the calendar years in the period 1964-1993, as well as the average for the entire sample (we average each variable over 12 months). For every year in the sample, the compounded daily returns, $R_{m, \tau}^{d}$, are greater than the monthly returns, $R_{m, \tau}$.

What is really surprising, however, is the magnitude of the difference (reported in column (3) of Table I). The average difference in annual returns is 6.04 percent, or about 0.427 percent per month. ${ }^{1}$ This difference is large, especially compared to a typical monthly return. In some years the difference is much greater. For example, in 1991, the annual return using the daily series is 62.9 percent, but the return using the monthly series is 42.13 percent, a difference of over 20 percent, or more than 1.2 percent on a monthly basis. This difference is large enough to reverse the conclusions of a paper using this benchmark to compute excess returns. ${ }^{2}$

\footnotetext{
${ }^{1}$ The average annual difference is calculated as the difference between the buy-and-hold portfolios based on these indices as reported in the last row of Table I, columns (1) and (2): $1.01794^{12}-1.012924^{12}$ $=0.0604$. Because of Jensen's inequality, this is not equal to the compounded monthly difference $\left(1.04269^{12}-1\right)$, which equals 5.25 percent on an annual basis.

${ }^{2}$ We can consider the comparison between the daily and monthly indices to be the same as the comparison of the one-month buy-and-hold strategy (the monthly index) to a daily rebalancing (the daily index), as described in Roll (1983) and in Blume and Stambaugh (1983). Thus, the fact that the daily index yields higher annual returns in every year of our sample period is a strong indication of negative daily serial dependence of securities' returns and positive serial dependence of the portfolio's returns.
} 
As Table II shows, the difference between the compounded daily returns and the monthly returns for the EW index is not constant across months. The largest difference, 0.66 percent, is in the month of December. ${ }^{3}$

In Table III, we report the months with the largest differences between the indices. The largest difference is 2.63 percent in July 1992. All the differences reported in this table are more than 1 percent per month. Surprisingly, only one January (1991) is included. Given the relation to the size effect, we would expect to see more Januarys on this list. There are four Octobers (including October 1987) and four Decembers on the list. No other month appears more than twice, and April and June do not appear at all. ${ }^{4}$

Finally, in Table IV, we report the number of months with positive returns and positive differences. The daily equal-weighted return is positive in 64.72 percent of the months (233 of the 360 months in the sample period), compared to 59.72 percent of the monthly equal-weighted index observations (214 months). There are the same number of months with positive return for the daily and the monthly value-weighted indices (218 months). Also, although there are only three months where the difference in the equally- weighted index is negative, there are 167 (46.39 percent) such months for the value-weighted index.

\footnotetext{
${ }^{3}$ It is interesting to compare the equal- and value-weighted portfolios by month (columns (1) and (4), or columns (2) and (5) in Table II). Consistent with Keim (1983) and Blume and Stambaugh (1983), the largest difference between the equal-weighted (a proxy for small cap stocks) and the value-weighted (larger cap stocks) portfolios comes in the month of January, and averages about 5 percent on a monthly basis.

${ }^{4}$ A similar analysis (not shown) of the months with the smallest differences reveals that the difference is only negative in 3 of the 360 months we analyze. Of the 20 months with the smallest difference, 5 are January.
} 


\section{Explaining the Differences Between the Daily and Monthly Indices}

What can explain the large and fluctuating differences between the daily and monthly equal-weighted index (hereafter referred to as Diff)? The papers by Blume and Stambaugh (1983) and Roll (1983) suggest that intertemporal dependencies in returns, including those produced by bid-ask bounce and non-synchronous trading, should be important related factors. Much of the autocorrelation in individual stock returns can be attributed to the bid- ask bounce and the short-term autocorrelation in the index to non-synchronous trading (e.g., Roll (1983), Lo and MacKinlay $(1988,1990))$. Thus, we measure these factors directly. Borrowing from Blume and Stambaugh, for each security and for the portfolio as a whole, we proxy for the returns variation that is due to the bid-ask bounce by the variation of the excess return relative to price.

The average turnover is another natural proxy for the bid-ask bounce and the effect of non-synchronous trading. Higher turnover is likely to be associated with lower non-synchronous trading and lower bid-ask bounce. This, in turn, should reduce the bias in the daily return.

Table V reports the mean, standard deviation, and the extreme values of each of the variables we use. We have already discussed the first two variables (Diff and the compounded daily index, $\left.R_{m, \tau}^{d}\right)$. The third variable is the cross-sectional variance in returns, $\operatorname{Var}\left(\bar{R}_{i}\right)_{t}$. We calculate each security's average return for any given month, and then find the cross-sectional variance of those returns. The next three variables, $\overline{\rho_{l 1}}, \overline{\rho_{l 2}}, \overline{\rho_{l 3}}$, are the first-, second-, and thirdorder average autocorrelations, respectively. Each security's autocorrelation for month $t$ is calculated from daily returns and averaged cross-sectionally. ${ }^{5}$ As expected, the average daily autocorrelation is negative and similar in magnitude to that reported by Lo and MacKinlay

\footnotetext{
${ }^{5}$ As there are 21 trading days in most months, we use 20 observations to compute the first-order autocorrelation, 19 to compute the second, and 18 to compute the third (missing observations are excluded).
} 
(1990). We also calculate the first-, second-, and third-order autocorrelations of the equalweighted portfolio, $\rho_{e w 1}, \rho_{e w 2} . \rho_{e w 3}$. Consistent with prior literature, the first-order portfolio autocorrelation is, on average, positive. The second- and third-order autocorrelations are negative, but much smaller. The average daily turnover of the securities in our sample, $\overline{T O_{l}}$, is calculated as the daily average turnover for each security in a given month, and then averaged across securities. Its mean value of 0.19 percent implies an annual turnover of approximately 49 percent. Even in frictionless markets where returns are temporally independent, the cross-section variation in returns will affect the difference (see Roll (1983)). Thus, the last two variables are the crosssectional average of the variation of excess return to price ratio, $\overline{\operatorname{Var}\left(R_{l} / P_{l}\right)}$ and the variation of the portfolio excess return relative to its price, $\overline{\operatorname{Var}\left(E R_{e w} / P_{e w}\right)}$. (Note: To calculate the portfolio variance, we calculate the ratio of excess return to price in each day in a month. We then calculate the variance of this series.) Both the standard deviation and the extreme values of all these variables indicate that their time-series variations are not trivial.

In Table VI we present the results of several regressions that are based on the variables described above. In all the regressions, the dependent variable is Diff , the difference between the monthly index compounded from the equal- weighted daily index, and the equal-weighted monthly index return. In the REG 1 column, we present the regression results based on the autocorrelation measures. The average first-order autocorrelation coefficient is negative (-0.03) and highly significant $(t=6.07)$. Thus, as the average autocorrelation of individual securities becomes more negative, the difference between the daily and the monthly indices increases. Similarly, the portfolio autocorrelation coefficient indicates that as the portfolio autocorrelation becomes more positive, the difference between the daily and the monthly indices increases. In both cases, the second-order autocorrelation coefficients take the opposite sign, but they are 
insignificantly different from zero. The third-order autocorrelations for the securities and for the portfolio are negative and positive, respectively. Both are significant. The cross-sectional variation is positive and significant (the simple univariate correlation is also positive). Thus, higher cross-sectional variability in stocks' returns results in a higher bias. It should be noted that the sign of this coefficient is the opposite of what the theory indicates (Roll (1983)). It is possible that this variable captures some deviation from the standard assumptions (normality and independence). ${ }^{6}$

It is interesting to compare the relative effect of the portfolio positive autocorrelation to the average negative autocorrelation of the individual securities on Diff. The mean portfolio autocorrelation is 20.22 percent, and the mean securities' autocorrelation is -6.255 percent. However, their coefficients are 0.0035 and -0.032 , respectively. Thus, the securities' autocorrelation has an effect that is more than two-and-one-half times larger than the portfolio autocorrelation effect. In other words, if most of the portfolio’s autocorrelation can be attributed to non-synchronous trading, but the securities autocorrelation is a result of a bid-ask bounce, then the bid-ask bounce has a larger effect on the difference than non-synchronous trading. ${ }^{7}$

\footnotetext{
${ }^{6}$ We also run the regression without the second and third autocorrelation terms. The $R^{2}$ drops only 1 percent (from around 21 percent in REG 1 to 20 percent). This result also assures us that it is not the correlation among the independent variables that drives the results.

${ }^{7}$ Another factor that may affect the difference between the two indices' returns is the dividend paid. (We would like to thank David Scharfstein for bringing this issue to our attention.) On the daily tape, each dividend is added to the price on the ex-day, while on the monthly tape the dividend is added to the price at the end of the month. Thus, if a security pays a dividend and experiences a positive return in the same month, the monthly index will lag the daily index by the return between the ex-day and the end of the month, multiplied by the dividend amount. If the return is negative, the monthly return will come ahead by the same factor. We calculate the monthly dividend for each stock multiplied by the return in that month. (Because we do not calculate the return from the ex-day to the end of the month, we implicitly assume in this calculation that on average dividends are being paid at the beginning of the month.) The average dividend multiplied by the return is positive ( 0.0881 percent). Thus, we can expect that, on average, it will bias the monthly return downward. However, its magnitude is very small relative to the average monthly return. We also add the cross-sectional average of this variable to the regressions described in Table V. Although its sign is positive, it is insignificantly different from zero.
} 
In the next set of regressions, we try alternative measures of bid-ask bounces and nonsynchronous trading. In particular, the average variation of the excess return to price measures the effect of the bid-ask bounce on individual securities, and the portfolio's variation of its excess return to price measures the effect on the index. REG 2 presents this result. The first thing we notice is that using a more direct measure of the bid-ask effect significantly increases the regression's $R^{2}$ (from approximately 22 percent when the autocorrelation is used to 47 percent here). Second, both coefficients are positive and highly significant. Third, the coefficient of the portfolio variation of excess return to price is positive and highly significant-the opposite of what we expected (see Blume and Stambaugh (1983)). In the REG 3 column, we add the firstorder autocorrelation terms, respectively. All coefficients are significant and their sign is consistent with prior analysis. The $R^{2}$ increases to almost 50 percent. As before, adding higherorder autocorrelation terms does not add much to the regression's explanatory power.

Another interesting variable is turnover. Higher turnover should result in a lower bid-ask bounce effect, and the non-synchronous trading problem should be less pronounced. Both effects should lead to a negative association between turnover and the difference. Higher turnover should result in a lower difference. Although the turnover coefficient is indeed negative, it is insignificant (reported in REG 4).

In summary, the difference between the daily and the monthly indices is larger in months where the index's return variation is higher, when the autocorrelation in the index returns is higher, when the cross-sectional variability in returns is higher, and when the average autocorrelation in individual returns is lower. Neither turnover nor dividends significantly affect the magnitude of the bias. 
Finally, a natural question about our results is whether the bias we report holds for portfolios of other sizes. For example, does the size of the bias depend on the number of stocks in the portfolio? We conduct a Monte Carlo analysis to evaluate whether the number of securities in an equal-weighted portfolio affects the difference between the compounded daily returns and monthly returns of the portfolio. We generate five sizes of equal-weighted portfolios of 10, 100, 300, 600, and 900 randomly selected securities from CRSP and compute the difference between the annualized compounded daily returns and the annualized monthly returns by portfolio for each month over the 1964-1993 period. This results in 360 runs for each of the five portfolio size groups - 30 years and 12 months per year. For example, for the 10- security portfolio groups, we randomly select ten companies that are publicly traded in January 1964 and then compute the difference between the annualized compounded daily return and annualized monthly return for this month. We then repeat this entire procedure for each month over the sample period. That is, we randomly select ten more securities that are publicly traded in February 1964 and compute the difference, and so on through the entire sample period. We repeat this process for each portfolio size group. We then compute the average difference (and the standard error of the average difference) across the 360 runs for each of the five portfolio size groups. The difference (on an annual basis) is 6.51 percent for the 10 -stock portfolio, 7.12 percent for the 100 -stock portfolio, 7.23 percent for the 300-stock portfolio, 7.19 percent for the 600 -stock portfolio, and 7.18 percent for the 900- stock portfolio. These results indicate that (1) a significant bias exists even for a portfolio of ten stocks, and (2) the bias has the same magnitude for all the portfolios we check. (It should also be noted that using daily returns to calculate a portfolio long-run return will result in a bias even if this portfolio is not being used as the benchmark portfolio. Thus this 
problem will affect event studies that compute daily returns on any equally-weighted portfolios in event time, regardless of the benchmark that is being used.)

\section{Conclusions}

The differences between the monthly returns compounded from the daily tapes and the monthly CRSP equal-weighted indices are very large. On average, the difference is almost 0.43

percent per month, which translates to 6 percent per year. This difference amounts to one-third of the average monthly return. For this reason, the daily EW index should be compounded only over very short time periods. About half of the difference between the compounded daily EW return and the monthly return can be explained by variables suggested by the theory. However, not all the variables have the correct signs.

Several strategies are available to avoid the problems highlighted here. The first is to use the value-weighted index as the benchmark portfolio. This portfolio does not suffer from any compounding related bias. A second alternative is to use the monthly equal-weighted index instead of the daily. However, if an equal-weighted return series is needed for any long period of time, then it is necessary to splice the monthly and daily tapes together. For example, if a oneyear return is needed from November 11, 1991, then the daily tape should be used to compute the returns for the remaining trading days in November 1991. This return is then added to the return for the next 11 months, using the monthly tape. Finally, the daily tape is used again for the first part of November 1992. This procedure reduces the bias substantially. Using the monthly instead of the daily equal-weighted index (the second alternative) results in a much smaller bias. In fact, the difference between a yearly buy-and-hold strategy and a monthly rebalancing strategy 
is very small (see Roll (1983)). ${ }^{8}$ A third alternative is to follow the approach of Roll (1983), Blume and Stambaugh (1983), Conrad and Kaul (1993), and others, and compute the buy-andhold return for the benchmark portfolio. Because the benchmark portfolio in the case discussed here is the CRSP equal- weighted index, we can calculate buy-and-hold returns by using the average price of the portfolio at the beginning and then at the end of the holding period (with dividends reinvested).

Clearly, the third alternative is the best: It produces an exact buy-and- hold portfolio that is clear of any biases. Further, this alternative does not restrict the researcher in the type of a benchmark portfolio that can be used- even if the index is not value-weighted, it will not result in a bias.

Until several years ago, this alternative was associated with a non-trivial cost. We had to construct such an index from scratch. ${ }^{9}$ However, CRSP now provides a daily price index (dividends included) for both the equal-weighted portfolio and for the ten size-decile portfolios. This index can be used to address this issue quite easily: we can simply retrieve the index level for the first day and for the last day to be included in the excess return calculation and then use these two numbers to calculate the appropriate buy-and-hold return on the benchmark portfolio.

\footnotetext{
${ }^{8}$ This argument abstracts from the issue of the cost of transacting. However, we do not try to advocate an actual monthly rebalancing of a portfolio, but the extent of the bias in its approximation of a true buy-andhold strategy (see also Barber and Lyon (1996)).

${ }^{9}$ Another potential disadvantage to constructing indices from scratch was that it was, and is, harder to replicate works that are done with "homemade" indices relative to the publicly available indices such as those on the CRSP tapes.
} 
Table I

\section{Monthly Average Returns on the CRSP Equal- and Value-Weighted Portfolios, by Year}

Monthly returns are calculated from either the daily tape or from the monthly tape. All returns are calculated for a one-month holding period (reported in percentage). The table reports the yearly averages of these variables for the 1964 to 1993 period.

\begin{tabular}{|c|c|c|c|c|c|c|}
\hline \multirow[b]{2}{*}{ Year } & \multicolumn{3}{|c|}{ Equal-Weighted Return (\%) } & \multicolumn{3}{|c|}{ Value-Weighted Return (\%) } \\
\hline & $\begin{array}{l}(1) \\
\text { Daily }\end{array}$ & $\begin{array}{c}(2) \\
\text { Monthly }\end{array}$ & $\begin{array}{c}(3) \\
\text { Difference }\end{array}$ & $\begin{array}{l}(4) \\
\text { Daily }\end{array}$ & $\begin{array}{c}(5) \\
\text { Monthly }\end{array}$ & $\begin{array}{c}(6) \\
\text { Difference }\end{array}$ \\
\hline 1964 & 1.8068 & 1.4167 & 0.3901 & 1.2718 & 1.2726 & -0.0008 \\
\hline 1965 & 2.9399 & 2.6433 & 0.2966 & 1.1549 & 1.1558 & -0.0009 \\
\hline 1966 & -0.1468 & -0.4320 & 0.2852 & -0.7103 & -0.7048 & -0.0055 \\
\hline 1967 & 5.2013 & 5.0146 & 0.1867 & 2.1717 & 2.1699 & 0.0017 \\
\hline 1968 & 3.2306 & 3.0855 & 0.1451 & 1.1937 & 1.1823 & 0.0114 \\
\hline 1969 & -2.0420 & -2.2326 & 0.1906 & -0.8613 & -0.8658 & 0.0044 \\
\hline 1970 & -0.2423 & -0.6377 & 0.3953 & 0.1962 & 0.1890 & 0.0072 \\
\hline 1971 & 2.0326 & 1.7448 & 0.2879 & 1.3202 & 1.3359 & -0.0157 \\
\hline 1972 & 0.7502 & 0.5305 & 0.2197 & 1.3663 & 1.3599 & 0.0064 \\
\hline 1973 & -2.7044 & -3.2039 & 0.4996 & -1.5146 & -1.4893 & -0.0253 \\
\hline 1974 & -1.4101 & -2.2898 & 0.8798 & -2.4040 & -2.4058 & 0.0019 \\
\hline 1975 & 5.4477 & 4.7686 & 0.6792 & 2.8106 & 2.8331 & -0.0225 \\
\hline 1976 & 4.1184 & 3.6295 & 0.4889 & 2.0540 & 2.0536 & 0.0005 \\
\hline 1977 & 1.5324 & 1.2413 & 0.2911 & -0.3204 & -0.3177 & -0.0027 \\
\hline 1978 & 2.0530 & 1.8210 & 0.2320 & 0.7382 & 0.7502 & -0.0119 \\
\hline 1979 & 3.2352 & 2.9841 & 0.2511 & 1.8595 & 1.8606 & -0.0011 \\
\hline 1980 & 2.9984 & 2.7291 & 0.2693 & 2.5432 & 2.5421 & 0.0011 \\
\hline 1981 & 0.7255 & 0.4832 & 0.2423 & -0.2995 & -0.2898 & -0.0097 \\
\hline 1982 & 2.6245 & 2.2817 & 0.3428 & 1.6884 & 1.6839 & 0.0044 \\
\hline 1983 & 2.9378 & 2.7194 & 0.2184 & 1.7799 & 1.7813 & -0.0014 \\
\hline 1984 & 0.0984 & -0.1704 & 0.2688 & 0.4757 & 0.4884 & -0.0128 \\
\hline 1985 & 2.4081 & 2.0676 & 0.3405 & 2.3421 & 2.3425 & -0.0004 \\
\hline 1986 & 1.4281 & 1.0473 & 0.3807 & 1.4340 & 1.4230 & 0.0111 \\
\hline 1987 & 0.4443 & 0.0051 & 0.4392 & 0.5993 & 0.6072 & -0.0079 \\
\hline 1988 & 2.1429 & 1.6372 & 0.5057 & 1.3897 & 1.3885 & 0.0013 \\
\hline 1989 & 1.8012 & 1.2973 & 0.5039 & 2.2290 & 2.2176 & 0.0113 \\
\hline 1990 & -0.8390 & -1.7774 & 0.9384 & -0.2917 & -0.2905 & -0.0012 \\
\hline 1991 & 4.1527 & 2.9331 & 1.2196 & 2.3393 & 2.3294 & 0.0099 \\
\hline 1992 & 2.5911 & 1.6665 & 0.9246 & 0.6592 & 0.6618 & 0.0026 \\
\hline 1993 & 2.2647 & 1.7697 & 0.4950 & 0.8831 & 0.8850 & -0.0019 \\
\hline $1964-93$ & 1.7194 & 1.2924 & 0.4269 & 0.9366 & 0.9383 & -0.0017 \\
\hline
\end{tabular}


Table II

\section{Mean Return on the CRSP Equal- and Value-Weighted Portfolios by Month of the Year}

Monthly returns are calculated from either the daily tape or from the monthly tape. All returns are calculated for a one-month holding period (reported in percentage). The table reports the average return by month. The sample period is 1964 to 1993 .

\begin{tabular}{|c|c|c|c|c|c|c|}
\hline \multirow[b]{2}{*}{ Month } & \multicolumn{3}{|c|}{ Equal-Weighted Return } & \multicolumn{3}{|c|}{ Value-Weighted Return } \\
\hline & $\begin{array}{c}(1) \\
\text { Daily }\end{array}$ & $\begin{array}{c}(2) \\
\text { Monthly }\end{array}$ & $\begin{array}{c}\text { (3) } \\
\text { Difference }\end{array}$ & $\begin{array}{c}(4) \\
\text { Daily }\end{array}$ & $\begin{array}{c}\text { (5) } \\
\text { Monthly }\end{array}$ & $\begin{array}{c}(6) \\
\text { Difference }\end{array}$ \\
\hline January & 7.2891 & 6.9210 & 0.3680 & 2.1537 & 2.1675 & -0.0138 \\
\hline February & 2.1724 & 1.8317 & 0.3407 & 0.8227 & 0.8164 & 0.0064 \\
\hline March & 2.2790 & 1.8753 & 0.4036 & 1.1103 & 1.1046 & 0.0057 \\
\hline April & 1.2686 & 0.8942 & 0.3744 & 1.1559 & 1.1568 & -0.0008 \\
\hline May & 0.7222 & 0.3165 & 0.4057 & 0.5537 & 0.5515 & 0.0022 \\
\hline June & 0.5792 & 0.2075 & 0.3717 & 0.4813 & 0.4830 & -0.0017 \\
\hline July & 1.0643 & 0.6343 & 0.4299 & 0.4294 & 0.4366 & -0.0072 \\
\hline August & 1.2583 & 0.8182 & 0.4401 & 1.1665 & 1.1735 & -0.0070 \\
\hline September & 0.6423 & 0.2722 & 0.3701 & -0.2916 & -0.2919 & 0.0003 \\
\hline October & 0.5030 & 0.9890 & 0.4860 & 0.4164 & 0.4296 & -0.0131 \\
\hline November & 1.6862 & 1.2144 & 0.4718 & 1.5153 & 1.5138 & 0.0015 \\
\hline December & 2.1740 & 1.5128 & 0.6612 & 1.7254 & 1.7184 & 0.0070 \\
\hline
\end{tabular}


Table III

\section{The 20 Highest Values of the Difference between the Daily and Monthly Returns on the CRSP Equal- and Value-Weighted Portfolios}

Monthly returns are calculated from either the daily tape or from the monthly tape. All returns are calculated for a one-month holding period (reported in percentage).

\begin{tabular}{|c|c|c|c|c|c|c|c|c|}
\hline \multirow[b]{2}{*}{ Rank } & \multirow[b]{2}{*}{ Year } & \multirow[b]{2}{*}{ Month } & \multicolumn{3}{|c|}{ Equal-Weighted Return } & \multicolumn{3}{|c|}{ Value-Weighted Return } \\
\hline & & & Daily & Monthly & Difference & Dasly & Monthly & Difference \\
\hline 360 & 1992 & July & 5.9198 & 3.2815 & 2.6383 & 4.0373 & 4.0608 & -0.0235 \\
\hline 359 & 1990 & December & 2.2664 & 0.2315 & 2.0349 & 2.8031 & 2.8139 & -0.0108 \\
\hline 358 & 1991 & January & 11.5095 & 9.6265 & 1.8830 & 4.2251 & 4.2090 & 0.0161 \\
\hline 357 & 1990 & November & 6.9907 & 5.2325 & 1.7582 & 6.2836 & 6.2802 & 0.0034 \\
\hline 356 & 1974 & December & -6.5474 & -8.3036 & 1.7562 & -2.4913 & -2.5092 & 0.0179 \\
\hline 355 & 1990 & October & -3.3829 & -5.0863 & 1.7034 & -0.9308 & -0.9418 & 0.0110 \\
\hline 354 & 1991 & December & 6.7064 & 5.0109 & 1.6955 & 10.5379 & 10.5060 & 0.0319 \\
\hline 353 & 1987 & October & -25.3020 & -26.7977 & 1.4962 & -21.8350 & -21.8140 & -0.0201 \\
\hline 352 & 1991 & November & -2.4194 & -3.7995 & 1.3801 & -3.7921 & -3.7868 & -0.0053 \\
\hline 351 & 1991 & March & 7.3624 & 6.0044 & 1.3580 & 2.4415 & 2.4367 & 0.0048 \\
\hline 350 & 1974 & September & -6.6759 & -7.9855 & 1.3096 & -11.0100 & -11.0090 & -0.0011 \\
\hline 349 & 1991 & October & 2.4147 & 1.1513 & 1.2634 & 1.5796 & 1.5632 & 0.0164 \\
\hline 348 & 1992 & May & 1.8649 & 0.6188 & 1.2461 & 0.5614 & 0.5571 & 0.0043 \\
\hline 347 & 1973 & December & -2.6004 & -3.8369 & 1.2365 & 1.3066 & 1.3024 & 0.0042 \\
\hline 346 & 1974 & October & 11.4452 & 10.2432 & 1.2020 & 16.5281 & 16.5285 & -0.0004 \\
\hline 345 & 1991 & August & 3.2769 & 2.1330 & 1.1439 & 2.4170 & 2.4062 & 0.0108 \\
\hline 344 & 1991 & February & 14.3984 & 13.2703 & 1.1281 & 7.3309 & 7.3109 & 0.0200 \\
\hline 343 & 1992 & March & -0.9605 & -2.0776 & 1.1171 & -2.0063 & -2.0077 & 0.0014 \\
\hline 342 & 1970 & May & -7.9395 & -9.0526 & 1.1128 & -6.4380 & -6.4342 & -0.0038 \\
\hline 341 & 1991 & July & 3.8768 & 2.8016 & 1.0752 & 4.5285 & 4.5279 & 0.0006 \\
\hline
\end{tabular}


Table IV

\section{Proportion of Positive Returns for Equal- and Value-Weighted Portfolios}

The number of months that experience positive returns are shown in columns (1) and (4) as calculated from the daily tapes, for the equal- and value-weighted indices respectively. Columns (2) and (5) report the results for returns calculated from the monthly tapes. Columns (3) and (6) report the number of months where the difference between the indices (daily and monthly) is positive. There are 360 months in the sample.

\begin{tabular}{lccccccc}
\hline & \multicolumn{3}{c}{ Equal-Weighted Return } & & \multicolumn{3}{c}{ Value-Weighted Return } \\
\cline { 2 - 3 } & $\begin{array}{c}(1) \\
\text { Daily }\end{array}$ & $\begin{array}{c}(2) \\
\text { Monthly }\end{array}$ & $\begin{array}{c}(3) \\
\text { Difference }\end{array}$ & & $\begin{array}{c}(4) \\
\text { Daily }\end{array}$ & $\begin{array}{c}(5) \\
\text { Monthly }\end{array}$ & Difference \\
\hline $\begin{array}{l}\text { Number of months } \\
\text { with positive }\end{array}$ & 233 & 214 & 357 & & 218 & 218 & 193 \\
$\begin{array}{l}\text { returns } \\
\text { Percentage positive }\end{array}$ & 64.72 & 59.72 & 99.16 & & 60.83 & 60.83 & 53.61 \\
\hline
\end{tabular}




\section{Table V \\ Descriptive Statistics}

Panel A presents the mean, standard error, and extreme values of each of the following variables. Diff, is the difference between the monthly index compounded from the equal-weighted daily index, and the equal-weighted monthly index. $R_{m, r}^{d}$ is the monthly portfolio return, compounded from the daily equal-weighted index. $\operatorname{Var}\left(\bar{R}_{i}\right)_{t}$ is the cross-sectional variance of the average returns. $\overline{\rho_{i 1}}, \overline{\rho_{i 2}}, \overline{\rho_{i 3}}$ are the average first-, second-, and third-order autocorrelations of each stock's return. $\rho_{\text {ew } 1}, \rho_{\text {ew } 2}, \rho_{\text {ew } 3}$ are the first-, second-, and third-order autocorrelation of the daily equal-weighted port folio in month $t . \overline{T O}_{i}$ is the average monthly turnover across stocks. $\overline{\operatorname{Var}\left(R_{i} / P_{i}\right)}$ is the cross-sectional average variance of return relative to price. $\operatorname{Var}\left(R_{e w} / P_{e w}\right)$ is the variance of return relative to price of the equal-weighted index. Panel B reports the correlation of these variables. The sample contains 360 monthly observations (Jan. 1964-Dec. 1993) on each of those variables.

Panel A: Summary Statistics

\begin{tabular}{|c|c|c|c|c|}
\hline Variable & Mean $(\times 100)$ & Std. Dev. $(\times 100)$ & Minimum $(\times 100)$ & Maximum $(\times 100)$ \\
\hline $\operatorname{Diff}_{\tau}$ & 0.4269 & 0.3433 & -0.1291 & 2.6383 \\
\hline$R_{m, \tau}^{d}$ & 1.7193 & 5.9148 & -25.3015 & 34.2199 \\
\hline $\operatorname{Var}\left(\overline{R_{i r}}\right)$ & 0.1092 & 0.6475 & 0.0256 & 12.3308 \\
\hline$\overline{\rho_{i 1}}$ & -6.2444 & 3.7275 & -13.6470 & 0.7217 \\
\hline$\overline{\rho_{i 2}}$ & -4.9932 & 2.3038 & -17.6720 & 0.1701 \\
\hline$\overline{\rho_{\imath 3}}$ & -4.7663 & 2.1129 & -12.6050 & 0.4972 \\
\hline$\rho_{e w 1}$ & 20.2226 & 19.9004 & -48.3770 & 63.9810 \\
\hline$\rho_{\text {ew } 2}$ & -3.2806 & 20.9622 & -70.5040 & 53.5090 \\
\hline$\rho_{\text {ew3 } 3}$ & -3.3439 & 18.7005 & -57.2820 & 52.5880 \\
\hline$T \overline{O_{1 r}}$ & 0.1930 & 0.0696 & 0.0654 & 0.4172 \\
\hline$\overline{\operatorname{Var}\left(R_{i} / P_{i}\right)}$ & 1.2617 & 4.5355 & 0.0002 & 46.4881 \\
\hline $\operatorname{Var}\left(R_{e w} / P_{e w}\right)$ & $5.5 \mathrm{E}-7$ & $1.5 \mathrm{E}-6$ & $1.0 \mathrm{E}-11$ & $2.02 \mathrm{E}-5$ \\
\hline
\end{tabular}

(con't) 
Panel B: Correlation Matrix

\begin{tabular}{|c|c|c|c|c|c|c|c|c|c|c|c|c|}
\hline Variable & $\overline{\mathrm{Diff} \tau}$ & $R_{m, r}^{d}$ & $\operatorname{Var}\left(\overline{R_{4}}\right)$ & $\overline{\rho_{i 1}}$ & $\overline{\rho_{i 2}}$ & $\overline{\rho_{i 3}}$ & $\rho_{e w 1}$ & $\rho_{w / 2}$ & $\rho_{\text {ew } 3}$ & $\overline{D_{i} R_{i} \tau}$ & $\overline{T O_{i \mathrm{r}}}$ & $\overline{\operatorname{Var}\left(R_{1} / P_{t}\right)}$ \\
\hline$R_{m, \tau}^{d}$ & $\begin{array}{l}0.073 \\
(0.16)\end{array}$ & $\begin{array}{r}1.000 \\
(0.00)\end{array}$ & & & & & & & & & & \\
\hline $\operatorname{Var}\left(\bar{R}_{i}\right)$ & $\begin{array}{r}0.380 \\
(0.00)\end{array}$ & $\begin{array}{c}0.053 \\
\langle 0.31\rangle\end{array}$ & $\begin{array}{r}1.000 \\
(0.00)\end{array}$ & & & & & & & & & \\
\hline $\bar{\rho}_{11}$ & $\begin{array}{r}-0.216 \\
(0.00)\end{array}$ & $\begin{array}{c}0.068 \\
(0.20)\end{array}$ & $\begin{array}{r}-0.046 \\
(0.38)\end{array}$ & $\begin{array}{r}1.000 \\
(0.00)\end{array}$ & & & & & & & & \\
\hline$\overline{\rho_{42}}$ & $\begin{array}{r}0.023 \\
(0.66)\end{array}$ & $\begin{array}{r}0.139 \\
(0.00)\end{array}$ & $\begin{array}{c}0.021 \\
(0.69)\end{array}$ & $\begin{array}{r}0.049 \\
(0.35)\end{array}$ & $\begin{array}{r}1.000 \\
(0.00)\end{array}$ & & & & & & & \\
\hline$\overline{\rho_{43}}$ & $\begin{array}{r}-0.004 \\
(0.94)\end{array}$ & $\begin{array}{r}-0.048 \\
(0.36)\end{array}$ & $\begin{array}{r}0.037 \\
(0.48)\end{array}$ & $\begin{array}{r}-0.257 \\
(0.00)\end{array}$ & $\begin{array}{r}0.359 \\
(0.00)\end{array}$ & $\begin{array}{r}1.000 \\
(0.00)\end{array}$ & & & & & & \\
\hline$\rho_{\text {w } 1}$ & $\begin{array}{c}0.031 \\
(0.55)\end{array}$ & $\begin{array}{c}-0.122 \\
(0.02)\end{array}$ & $\begin{array}{r}-0.049 \\
(0.34)\end{array}$ & $\begin{array}{r}0.469 \\
(0.00)\end{array}$ & $\begin{array}{c}0.224 \\
(0.00)\end{array}$ & $\begin{array}{r}-0.019 \\
(0.71)\end{array}$ & $\begin{array}{r}1.000 \\
(0.00)\end{array}$ & & & & & \\
\hline$\rho_{\text {ww2 } 2}$ & $\begin{array}{l}0.003 \\
(0.95)\end{array}$ & $\begin{array}{r}0.007 \\
(0.89)\end{array}$ & $\begin{array}{c}-0.044 \\
(0.40)\end{array}$ & $\begin{array}{r}0.127 \\
(0.01)\end{array}$ & $\begin{array}{c}0.816 \\
(0.00)\end{array}$ & $\begin{array}{c}0.252 \\
(0.00)\end{array}$ & $\begin{array}{r}0.350 \\
(0.00)\end{array}$ & $\begin{array}{r}1.000 \\
(0.00)\end{array}$ & & & & \\
\hline$\rho_{\text {ew } 3}$ & $\begin{array}{c}0.005 \\
(0.92)\end{array}$ & $\begin{array}{c}-0.045 \\
(0.89)\end{array}$ & $\begin{array}{c}0.010 \\
(0.84)\end{array}$ & $\begin{array}{c}-0.046 \\
(0.38)\end{array}$ & $\begin{array}{c}0.289 \\
(0.00)\end{array}$ & $\begin{array}{c}0.795 \\
(0.00)\end{array}$ & $\begin{array}{r}0.037 \\
(0.48)\end{array}$ & $\begin{array}{c}0.309 \\
(0.00)\end{array}$ & $\begin{array}{r}1.000 \\
(0.00)\end{array}$ & & & \\
\hline$\overline{D_{i} R_{i r}}$ & $\begin{array}{c}0.001 \\
(0.99)\end{array}$ & $\begin{array}{r}0.819 \\
(0.00)\end{array}$ & $\begin{array}{c}0.014 \\
(0.79)\end{array}$ & $\begin{array}{c}0.032 \\
(0.54)\end{array}$ & $\begin{array}{c}0.169 \\
(0.00)\end{array}$ & $\begin{array}{c}0.049 \\
(0.35)\end{array}$ & $\begin{array}{c}-0.123 \\
(0.02)\end{array}$ & $\begin{array}{c}0.005 \\
(0.92)\end{array}$ & $\begin{array}{c}-0.009 \\
(0.87)\end{array}$ & $\begin{array}{r}1.000 \\
(0.00)\end{array}$ & & \\
\hline$\overline{T O_{i}}$ & $\begin{array}{c}-0.061 \\
(0.24)\end{array}$ & $\begin{array}{c}0.172 \\
(0.00)\end{array}$ & $\begin{array}{c}0.036 \\
(0.49)\end{array}$ & $\begin{array}{c}0.318 \\
(0.00)\end{array}$ & $\begin{array}{c}-0.068 \\
(0.20)\end{array}$ & $\begin{array}{c}-0.184 \\
(0.00)\end{array}$ & $\begin{array}{c}-0.235 \\
(0.00)\end{array}$ & $\begin{array}{c}-0.054 \\
(0.30)\end{array}$ & $\begin{array}{c}-0.054 \\
(0.30)\end{array}$ & $\begin{array}{c}0.176 \\
(0.00)\end{array}$ & $\begin{array}{r}1.000 \\
(0.00)\end{array}$ & \\
\hline$\overline{\operatorname{Var}\left(R_{i \tau} / P_{i \tau}\right)}$ & $\begin{array}{c}0.561 \\
(0.00)\end{array}$ & $\begin{array}{r}0.067 \\
\langle 0.20\rangle\end{array}$ & $\begin{array}{c}0.069 \\
(0.19)\end{array}$ & $\begin{array}{c}-0.165 \\
(0.00)\end{array}$ & $\begin{array}{c}0.054 \\
(0.30)\end{array}$ & $\begin{array}{r}-0.005 \\
(0.92)\end{array}$ & $\begin{array}{r}-0.011 \\
(0.89)\end{array}$ & $\begin{array}{r}0.006 \\
(0.91)\end{array}$ & $\begin{array}{r}-0.028 \\
(0.60)\end{array}$ & $\begin{array}{c}0.048 \\
(0.36)\end{array}$ & $\begin{array}{r}0.114 \\
(0.03)\end{array}$ & $\begin{array}{r}1.000 \\
(0.00)\end{array}$ \\
\hline $\operatorname{Var}\left(R_{e w} / P_{e w}\right)$ & $\begin{array}{c}0.143 \\
(0.00)\end{array}$ & $\begin{array}{c}-0.206 \\
(0.00)\end{array}$ & $\begin{array}{c}-0.024 \\
(0.65)\end{array}$ & $\begin{array}{c}0.151 \\
(0.00)\end{array}$ & $\begin{array}{c}-0.182 \\
(0.00)\end{array}$ & $\begin{array}{c}-0.081 \\
(0.12)\end{array}$ & $\begin{array}{c}0.136 \\
(0.00)\end{array}$ & $\begin{array}{c}-0.048 \\
(0.37)\end{array}$ & $\begin{array}{c}-0.029 \\
(0.58)\end{array}$ & $\begin{array}{c}-0.285 \\
(0.00)\end{array}$ & $\begin{array}{c}-0.229 \\
(0.00)\end{array}$ & $\begin{array}{c}-0.091 \\
(0.08)\end{array}$ \\
\hline
\end{tabular}




\section{Table VI}

\section{The Difference between the Daily and Monthly Returns on the CRSP Equal-Weighted Portfolios}

The dependent variable is the difference between the monthly index compounded from the equal-weighted daily index and the equal-weighted monthly index, (Difft). The independent variables: $\rho_{e w 1}, \rho_{e w 2}, \rho_{e w 3}$ are the first-, second-, and third-order autocorrelation of the daily equally weighted portfolio in month $t . \overline{\rho_{i 1}}, \overline{\rho_{i 2}}, \overline{\rho_{i 3}}$ are the average first-, second-, and third-order autocorrelation of each stock's return. $\operatorname{Var}\left(\bar{R}_{i}\right)_{t}$ is the cross-sectional variance of the average returns. $\operatorname{Var}\left(R_{e w} / P_{e w}\right)$ is the variance of return relative to price of the equal-weighted index. $\overline{\operatorname{Var}\left(R_{i} / P_{i}\right)}$ is the cross-sectional average variance of return relative to price. $\overline{T O_{i}}$ is the average monthly turn-over across stocks. The sample contains 360 monthly observations (Jan. 1963Dec. 1993). Parameter estimates are reported in the body of the table and absolute values of $t$-statistics are in parentheses.

\begin{tabular}{|c|c|c|c|c|}
\hline Variable & REG 1 & REG 2 & REG 3 & REG 4 \\
\hline Intercept & $\begin{array}{c}-0.00004 \\
(0.04)\end{array}$ & $\begin{array}{c}0.00329 \\
(22.29)\end{array}$ & $\begin{array}{l}0.00173 \\
(4.70)\end{array}$ & $\begin{array}{l}0.00476 \\
(9.64)\end{array}$ \\
\hline$\overline{p_{i 1}}$ & $\begin{array}{c}-0.03216 \\
(6.07)\end{array}$ & & $\begin{array}{c}-0.01854 \\
(4.65)\end{array}$ & \\
\hline$\overline{\rho_{i 2}}$ & $\begin{array}{l}0.01084 \\
(0.83)\end{array}$ & & & \\
\hline$\overline{\rho_{t 3}}$ & $\begin{array}{l}-0.04173 \\
(2.88)\end{array}$ & & & \\
\hline$\rho_{e w 1}$ & $\begin{array}{l}0.00355 \\
(3.613)\end{array}$ & & $\begin{array}{l}0.00206 \\
(2.80)\end{array}$ & \\
\hline$\rho_{e w / 2}$ & $\begin{array}{c}-0.00092 \\
(0.63)\end{array}$ & & & \\
\hline$\rho_{\text {ew3 }}$ & $\begin{array}{l}0.00326 \\
(2.12)\end{array}$ & & & \\
\hline $\operatorname{Var}\left(\bar{R}_{i}\right)$ & $\begin{array}{l}0.20041 \\
(8.02)\end{array}$ & $\begin{array}{l}0.18379 \\
(8.98)\end{array}$ & $\begin{array}{l}0.18333 \\
(9.20)\end{array}$ & $\begin{array}{l}0.20300 \\
(7.84)\end{array}$ \\
\hline $\operatorname{Var}\left(R_{i r} / P_{i r}\right)$ & & $\begin{array}{l}0.04208 \\
(14.35)\end{array}$ & $\begin{array}{l}0.03974 \\
(13.72)\end{array}$ & \\
\hline$\overline{\operatorname{Var}\left(R_{\text {ew }} / P_{\text {ew }}\right)}$ & & $\begin{array}{c}448.39 \\
(5.23)\end{array}$ & $\begin{array}{r}473.42 \\
(5.60)\end{array}$ & \\
\hline$\overline{T O_{i r}}$ & & & & $\begin{array}{c}-0.37003 \\
(1.54)\end{array}$ \\
\hline$R^{2}$ & 0.2134 & 0.4682 & 0.4967 & 0.1454 \\
\hline
\end{tabular}




\section{References}

Barber, Brad, and John Lyon, 1996, Detecting long-run abnormal stock returns: The empirical power and specification of test statistics, Journal of Financial Economics 41, 359-399.

Bernard, Victor, and Jacob Thomas, 1989, Post-earnings-announcement drift: Delayed price response or risk premium?, Journal of Accounting Research 27, 1-36.

Blume, Marshall, and Robert Stambaugh, 1983, Biases in computed returns: An application to the size effect, Journal of Financial Economics 12, 387-404.

Conrad, Jennifer, and Gautam Kaul, 1993, Long-term market reaction or biases in computed returns?, Journal of Finance 48, 39-63.

DeBondt, Werner, and Richard Thaler, 1985, Does the stock market overreact?, Journal of Finance 40, 793-805.

Ikenberry, David, Josef Lakonishok, and Theo Vermaelen, 1995, Market underreaction to open market stock repurchases, Journal of Financial Economics 39, 181-208.

Lo, Andrew, and Craig Mackinlay, 1988, Stock market prices do not follow random walks: Evidence from a simple specification test, Review of Financial Studies 1, 41-66.

Lo, Andrew, and Craig Mackinlay, 1990, When are contrarian profits due to stock market overreaction?, Review of Financial Studies 3, 175-205.

Keim, Donald, 1983, Size related anomalies and stock return seasonality: Further empirical evidence, Journal of Financial Economics 12, 13-32.

Michaely, Roni, Richard Thaler, and Kent Womack, 1995, Price reactions to dividend initiations and omissions: Overreaction or drift?, Journal of Finance 50, 573-608.

Reinganum, Marc, 1981, Misspecification of capital asset pricing: Empirical anomalies based on earnings’ yields and market values, Journal of Financial Economics 9, 19-46. 
Ritter, Jay, 1991, The long-run performance of initial public offerings, Journal of Finance 46, 127.

Roll, Richard, 1983, On computing mean returns and the small firm premium, Journal of Financial Economics 12, 371-386. 